\title{
Pioneering urban practices in transition spaces
}

\author{
Paola Pittaluga* ${ }^{*}$
}

\begin{abstract}
The article suggests a set of design requirements to orient urban practices of transformation and space management when they work on transition spaces, which are difficult to interpret and classify in accordance with traditional dichotomous categories such as centre/periphery, urban/not urban, open/closed, abandoned/lived, public/private. The first part of the article explains how various disciplines describe and characterise this kind of space, which cannot be described precisely through traditional categories. Literature search indicates how transition spaces have a number of attributes that can be translated into requirements to steer design actions. The examples of urban practices, described in the central paragraphs of the article, quickly show how project actions actualize the requirements that can be inferred both from literature and from the examples themselves. The conclusions summarise the design requirements to transform and manage transition spaces, in order to orient "pioneering urban practices", thus opening the way to different modes of intervention and offering new insights into the role of designers and users in this particular kind of practice. Promising prospects emerge not only for the design methodology of this type of spaces, but also for the possibility of addressing relevant issues in the current disciplinary debate concerning, on the one hand, the liveability and care of urban spaces and therefore the regeneration of public space, at a time in history when its existence is questioned, on the other hand the effectiveness of the involvement and empowerment of local societies in the processes of space transformation.
\end{abstract}

Keywords: Transition space, In between space, Flexibility, Subversiveness, Empowerment pioneering urban practices

\section{Transition spaces}

City, landscape, territory, often appear as an arrangement of well-defined and delimited spaces, with clear and defined functions.

But, looking closer at them and putting apart traditional, dichotomous categories of interpretation-such as center/periphery, urban/not-urban, open/closed, abandoned/lived, public/private-these spaces become not so easily recognizable anymore, blur into each other, and seem like porous and fragmented.

Its borders are not always one-dimensional, but more often bi-dimensional or even three-dimensional if we

*Correspondence: pittaluga@uniss.it

Dipartimento di Architettura, Design e Urbanistica, Università degli Studi di Sassari, Sassari, Italy also consider the temporal dimension as one of the peculiar features connoting them.

Thus, their boundaries are also made of interstices, voids, and spaces, which do not have a defined identity, where the presence and correlation of different dimensions is not uniquely characterizable.

These borders are actually in-between spaces, characterised by co-presence and intermediateness, an edge between different situations that encompasses, for example, residual and indefinite spaces, neither constrained nor used in accordance with traditional rules, or transition spaces between different part of city, between city and country, disused areas, and so on.

These spaces often reveal the environmental crisis and recall the social one (Guattari 1996b). They are no man's lands where the environment processes waste, thus characterising its shape. These are the results of the design
Springer Open

(c) The Author(s) 2020. This article is licensed under a Creative Commons Attribution 4.0 International License, which permits use, sharing, adaptation, distribution and reproduction in any medium or format, as long as you give appropriate credit to the original author(s) and the source, provide a link to the Creative Commons licence, and indicate if changes were made. The images or other third party material in this article are included in the article's Creative Commons licence, unless indicated otherwise in a credit line to the material. If material is not included in the article's Creative Commons licence and your intended use is not permitted by statutory regulation or exceeds the permitted use, you will need to obtain permission directly from the copyright holder. To view a copy of this licence, visit http://creativeco mmons.org/licenses/by/4.0/. 
practices (Boddington 1999) of architecture and urban planning but also of social practices (Brunet-Jailly 2011; Cohen 2000; van Houtum et al. 2005; Pile 1997). These practices infinitely produce boundaries, limits and borders, together with desires, passions and rights that are continuously de-singularised and regenerated (Bianchetti 2016).

The disciplinary tradition of urban planning, though, very often deals with these blurred and uncertain spaces through traditionally established planning and design techniques, policies, and forms of rationality, trying to bring them back to a standardised concept of common good and to generic and a priori defined needs.

Many of the resulting interventions proved themselves to be finally unsuccessful, or came to a halt because of lack of funds, of involvement, or because of conflicts over use or management, or again because of strict laws and constraints.

Dichotomous categories, which traditionally structure the disciplinary analysis and praxis, leading to a new reductionist functionalism (Bianchetti 2016), clearly fail in describing these spaces. This failure leads to the emergence of alternative-and in a certain way subversive when they do not comply with, or circumvent existing rules and laws-approaches and categories that focus on transitions, precisely in-between, situations (Amphoux 2003; Brighenti 2013; De Certeau 1984; Hall 1996; Leontidou 1996; Marras 1999).

\section{Liminality, edges, borders and in-betweenness}

Some categories and approaches start from liminality, a philosophical and cultural concept based on dialectical interaction rather than opposition. Liminality refers to a space where different dimensions (cultural, political, temporal, social, historical, etc.) co-exist and relate each other.

Disciplinary literature interprets liminal space, inbetween, or transition, both spatially and temporally, in various ways (Hazel and Les 2012; Horvath et al. 2015; Iossifova 2013; Jones 2009; Swerts 2017; Thomassen 2014).

Sievert (2003) defines the urbanized territory, that forms the periphery of cities between urban and rural, as "intermediate city" or zwischenstadt, while de Sola Morales and Clément call terrain vagues (de Sola Morales 1995) and "third landscape" (Clément 2004) the set of interstitial and residual spaces, of ruptures generated by decommissioning, by urban infrastructures, or by functional changes, which became a privileged ground for biological diversity to emerge.

The vast space between city and country, a territory that is more than the sum of its parts, is often called fringe in urban-planning literature (Furuseth and
Lapping 1999; Gallant et al. 2004, 2006; Gallant and Andersson 2007). Fringes are subject to continuous pressures exerted by rural and urban activities and become trapped between the need for growth and transformation and the desire for protection (Gallant et al. 2006).

According to Lévesque (2003) and Berger (2007), inbetween space is an interstitial space without a precise destination or use, which find place for an indefinite period of time between functionally determined spatial arrangements and are suitable for the development spontaneous practices. Therefore, they could be considered as a resource (Lévesque 2002).

Landscape urbanism, an interstitial discipline that works within spaces between buildings, infrastructural systems, natural ecologies, provides a similar interpretation for in-between spaces. City voids are "reserves of indeterminacy", potential places for action, available, flexible and open areas (Corner 2001, Waldheim and SantosMunne 2001).

Foucault (1994, 1998) and Merrifield (2000) recognize the liminal space as the one that coincides with the space of everyday experience, the lived space, where liminality resides in the simultaneous interconnection of the "traditional" space with (and by difference from) the daily space.

According to the post-colonialist approach of Routledge (1996) the third space is a place where people can challenge, change or maintain social relations, processes and/or institutions.

As stated by Bhabha $(1990,1996,2001)$, the third space or in-between is a liminal space "that represents a possibility for a cultural hybridity that entertains difference without an assumed or imposed hierarchy" (Bhabha 1994, p. 4). This is a space that originates by encountering otherness, is a space of communication, ${ }^{1}$ of negotiation and translation from one perspective to another, in a continuous redefinition of the identity of those involved in the process.

States, situations or identities that are transitional, according to Smith (2001), are also in-between, while Soja describes in-between space as an alternative to binary oppositions, which appears as a politicized place of possibilities (Soja 1996, 2000), because it creates opportunities for negotiation in order to identify new ways of using space through needs and uses expressed by the society (Soja 1989).

The third space may also emerge from a temporal variation in the use of a place or even a "temporary autonomous zone", defined by Bey as a place that suddenly

\footnotetext{
${ }^{1}$ On the concept of the border as an epistemologically privileged space of communication, see Cassano (1997) and Tagliagambe (1997).
} 
becomes free between preceding and following moments that are not free at all.

In these spaces the vertical hierarchy of power is spontaneously replaced with networks of horizontal relations (Bey 1991). These spaces become capable of materializing freedom because they are able to escape the established order.

In them, more than elsewhere, it is possible to transgress the rules and therefore also to experiment new ones (Galdini 2017).

From these various declinations of the concept emerges how the transition space, being blurred, becoming at once everything and nothing, belonging to everyone and nobody, and not subjected to traditional logics of appropriation and transformation of space, is a propitious place to explore and experiment new strategies for alternative urban use and organisation. ${ }^{2}$

Moreover, it is possible to observe how some characteristics and potentialities of these spaces recur in literature. In particular, several authors agree that it is possible (1) to subvert the rules that usually govern these spaces (social, political, economic), (b) to trigger spontaneous processes of appropriation and management of space, (c) to experiment new ways of use, (d) to maintain and increase diversity ${ }^{3}$ and thus to favour communication between different subjects, cultures and ideas, paving the way for hybridisation, and (e) to orient project actions to flexibility.

These concepts can be considered as design requirements to guide the transformation and management of transition spaces. They can be conveniently summarized in flexibility, spontaneous appropriation/reappropriation, subversiveness and empowerment.

It could be useful, indeed, to further specify the meaning of these requirements.

Flexibility is understood as flexible organization of space, functions and uses.

Similarly, spontaneous appropriation/reappropriation refers to those situations in which local societies, inhabitants, users decide autonomously to recover, transform, use a space without going through the traditional urban planning processes, thus often acting without having title, without authorization, intentionally or unintentionally.

Subversiveness has to do with the previous requirement and concerns practices which are deliberately confrontational, illegal, ${ }^{4}$ insurgent (Beard 2003; Douglas and Friedmann 1998; Holston 2008; Hou 2010; Miraftab

\footnotetext{
${ }^{2}$ Worpole and Knox (2007) argue that urban areas today require precisely spaces where to carry out behaviors that elsewhere can be defined as antisocial.

${ }^{3}$ It is worth noting how Crosta (2010) reflects on the fact that traditional practices do not build on diversity, but emphasise unitary visions instead.
}

2009; Roy 2009), and rebellious against the homologating forms of rationality.

Subversiveness therefore characterizes those situations in which attempts are made to break down the preestablished order of things, the accepted practices, the stereotypes, the clichés, and the hetero-direct forces disconnected from the local contexts of action.

Subversiveness is closely linked to empowerment (Bailey 2010; Douglas and Friedmann 1998; Friedman 1992, 2000; Fung 2004; Harvey 2000a; Holston 1998; Lane 2000; Sandercock 2000; Singh and Titi 1995; Weissberg 1999), to strengthen the actions of the residents, often gathering in marginal and weak groups, to satisfy their "spatial" needs in the processes resulting in spatial transformation.

Empowerment means building practices to strengthen the contractual power of residents (typically minorities) against both local and central governments, and to resolve everyday problems without turning to global projects, by highlighting differences and activating transactive and interpersonal processes that "cross borders" and connect local and global.

\section{Urban pioneering practices in transition spaces}

Moving from a theoretical sphere, such as that described in the previous paragraph, to a more practical one, if we look at some design experiences developed in recent years, we can notice the emergence the same concepts and requirements.

The following projects and design practices can be considered "pioneering urban practices" in the sense that they open the way to creative, subversive, empowermentoriented forms of spatial transformation. These practices offer promising prospects not only for the design of this type of spaces, but also for the possibility of addressing relevant issues in the current disciplinary debate concerning, on the one hand, the liveability and care of urban spaces and therefore the regeneration of public space, ${ }^{5}$ at a time in history when its existence is questioned, on the other hand the effectiveness of the involvement and empowerment of local societies in the processes of space transformation.

The pioneering urban practices illustrated here do not claim to be exhaustive. They are not case studies, but

\footnotetext{
${ }^{4}$ In literature there are Placemaking, Guerrilla Urbanism, Pop-up Urbanism, Urban Hacking or, in summary, approaches named Do It Yourself Urbanism (DIY). See among many Finn (2014), Douglas (2018) and Talen (2015).

5 For Hajer and Reijndorp (2001) a new concept of public space can often be found in intermediate and transition spaces, which are liminal: "border crossings, places where the different worlds of the inhabitants of the urban field touch each other" (p. 128). Bianchetti (2016) argues that today public space must be declined according to the concepts of property, accessibility, law (p. 48) desires and passions (p. 60).
} 
examples from which to draw the design requirements mentioned above, by deduction or abduction. They also show how the proposed actions modulate and actualize the same design requirements, or even just work as probes to test and better understand the strategies of intervention.

Some among them "meet" multiple requirements simultaneously (see table), although they are listed as matching a single requirement for clarity.

\begin{tabular}{llll}
\hline & Flexibility & $\begin{array}{l}\text { Spontaneous } \\
\text { approriation/ } \\
\text { reappropriation }\end{array}$ & $\begin{array}{l}\text { Subversiveness } \\
\text { and } \\
\text { empoverment }\end{array}$ \\
\hline Assemble & & $\times$ & $\times$ \\
Belo Horizonte & & $\times$ \\
Campement Urbain & & $\times$ & $\times$ \\
Cirugeda & $x$ & $x$ & \\
HPO & $x$ & $x$ & \\
Madrau & $x$ & $x$ & $\times$ \\
Orizzontale & $x$ & & \\
Recetas Urbana & & $x$ & \\
Yes we camp & & & \\
\hline
\end{tabular}

\section{Flexibility}

The blurred quality of transition spaces favours the flexibility and lightness of design as elements for the regeneration and the increase of urban character in poor and peripheral contexts. The following examples propose interventions on transition spaces which are able to change the way in which users perceive them.

Sometimes the site is a public space that is not public anymore: no longer a meeting space, it only keeps its connotation of a space of dispute in a city structured by noncommunicating and excluding fragments that foment distrust for difference (Cicalò 2006), when they become an element of separation between different social, cultural and ethnic realities.

The project for the regeneration of a public space by Valentina Madrau operates in this direction. A marginal area of the historic centre of Sassari becomes a space designed to keep a potential amount of transformation and allow the user to modify it according to their wishes.

The presence of different socio-cultural and ethnic groups which are also associated with different concepts and methods of use and appropriation of space, and in particular of public space, leads to create a place as varied and flexible as possible: its elements can actually be relocated by the users at all times, giving the opportunity for different ways of use.

The seats are of two types, both mobile: a first type consists of simple elements $2 \mathrm{~m}$ long, the other elements are actually flowerbeds, raised from the ground and surrounded by a lower surface, which allows up to three people on each side to sit and talk together.

Flexibility can be achieved through a system of tracks on which the elements can slide, pivoting around a pin placed at the base, which offers the maximum degree of freedom possible.

Distance and length of the tracks are not arbitrary but are designed to configure spaces that allow passing through and at the same time encourage social interaction.

The combination of the elements is extremely variable. The benches can be scattered, rotated, brought closer, aligned at the end of the area covered by the tracks to form "tribunes" and to leave a very large free central space, able to accommodate stages, exhibitions, but also fields for sports activities, etc.

The resulting area could accommodate three soccer fields or six volleyball courts, three basketball courts, sixteen play areas for table tennis, or 359 tables for a chess tournament or others board game.

The search for flexibility also distinguishes part of the work of the collective Orizzontale, which proposes "unstable" architectures, temporary, dynamic.

Nomadic objects configure instant squares, temporary fittings that may be reorganized according to any need, atypical buildings assembled and dismantled in a few hours using scaffolding, waste material, urban ready-made.

Some of these works insist on sites left free by others, creating concatenations in time and giving rise to a never-ending public space in perpetual motion.

The privileged places to experience this type of architecture are the residual spaces where people can find answers to new social needs through the experimentation of new modalities of intervention in the public realm, optimizing the available resources and creating a synergy between different types of "municipal waste".

Somehow, Orizzontale paradoxically recognizes that today encounter, relationship, and acknowledgment of the differences take place just in the marginal space, whose edges are not clearly defined: no men's lands without fences that ascribe them to any form of property, and without restrictions of access and use, just lived by individuals who seek in these spaces a freedom that is difficult to find within the traditional city (Cicalò 2001).

\section{Spontaneous appropriation/reappropriation}

In the urban residual areas, it is possible not only to explore different design practices, but also to activate processes of appropriation or reappropriation by citizens to promote the sense of belonging, involvement, sociality.

\footnotetext{
${ }^{6}$ See http://www.orizzontale.org/chi-siamo/. Accessed 12 Aug 2020.
} 
In disused urban spaces and in physically marginal terrain vagues, people can appropriate space because the edge, the transition space, can easily become a space available for spontaneous activities and behaviours.

Thus, Yes we camp, ${ }^{7}$ a collective that conceives its projects as "temporary common spaces" capable of increasing the natural relations between those who live in the same environment, fights against the obstacles found in contemporary urban life: high costs, distrust and conflict, professional, spatial and social fragmentation.

Their proposals are prototypical antidotes to these obstacles because they "authorize" the creation of hospitable and fertile spaces, where they support the maximization of the use of resources (particularly the ground) and the involvement of citizens.

Thus, they aim at setting reasonable deadlines, ignoring land value, investing in the short term, accepting and welcoming vulnerability, and feeding on reality, to awaken collective capacity and to give space to social exchange.

Emblematic is the Foresta project, which started in 2015 and is continuously being implemented, considered as "the collective emergence of a metropolitan park".

The intervention covers 20 hectares of hills, almost natural embankments to the construction of the shopping mall Grand Littoral, in the northern part of the city Marseille.

It acts like a blank sheet on which people can collectively imagine how to transform these spaces into a "metropolitan park" through the involvement of residents and local actors ${ }^{8}$ such as the Hôtel du Nord or the collective Safi and Résiliance society.

The idea is to define a space in which people can wander freely, but also learn, meet and express their talents.

Their method is iterative: it develops through a series of exchanges, on-site workshops, exploratory walks, events... and at the same time, it elaborates the projects for the realization of a farm, a grocery store to sell edible products obtained from species present in the site, amusement facilities. ${ }^{9}$

Another design of the collective is Vive les Groues,from the present to build the future-an initiative in Nanterre held in 2018 to transform a wasteland of 9000 square meters, with the conviction that what takes place there from now on can help to define the future scenario.

Therefore, planting trees, offering green space, sharing a workshop, revealing local stories, organizing meetings, seminars and festive moments become the way to bring out an identity and specific uses to the urban scale. ${ }^{10}$

The theme of reappropriation also characterizes Supercinema (December-October 2018), designed by the HPO Collective that ranges between architecture, design and performing arts (Stefani 2019).

Supercinema is a special installation in a square in Ferrara, Piazza Gobetti, where once stood the Apollo cinema, a very important meeting place for the people of Ferrara that became a depleted parking lot.

The collective's work favours a reappropriation by the inhabitants and celebrates the memory of the place through an intervention that recreates the nostalgic atmosphere of Apollo, with two building-site fences supporting a polycarbonate screen and a projector.

The module composed by the two fences and the screen repeats itself ten times and tells ten different stories, using the audio-visual material of the cultural association "Il Turco"."

\section{Subversiveness and empowerment}

Of all the requirements, however, subversiveness and empowerment are the most significant and relevant to orientate urban pioneering practices in transition spaces between different environments, situations and sizes.

This is especially true if the transition space coincides with a no-man's land. In this case, transition spaces are places of indeterminacy that oppose the urban transformations surrounding them (Lim 2001). Although they often welcome weakness, poverty, and marginalisation, they are also capable of welcoming subversiveness, art, and radicality: they are therefore vibrant with life and possibilities for evolution.

Moreover, the peripheral, degraded and abandoned spaces, which offer themselves to be "colonized" because they are no-man's lands, can represent an answer to the need for re-subjectivation by the individuals who live in them (Entrikin 1991; Greif and Cruz 1999; Guattari 1991) and can more than others favour social integration (Campos and García 2004; Sabatini and Arenas 2000), selforganization (Cellamare 2019; Paba 2003; Mukhija and Loukaitou-Sideris 2014; Roy 2005, 2009; Van Ballegooijen and Rocco 2013), collective learning, collaboration and cooperation (Gutiérrez et al. 1999, 2000), empowerment of the many possible and potential subjects (individual or collective).

\footnotetext{
${ }^{7}$ See https://yeswecamp.org/?page_id=1955. Accessed 12 Aug 2020.

8 See https://parcforesta.org/index.php/2018/12/13/organisateurs-et-contr ibuteurs/. Accessed 12 Aug 2020.

9 See https://yeswecamp.org/?page_id=163. Accessed 12 Aug 2020.
}

\footnotetext{
${ }^{10}$ See https://yeswecamp.org/?page_id=718. Accessed 12 Aug 2020.

11 See https://www.collater.al/creators-collettivo-hpo-design-architecture/. Accessed 12 Aug 2020.
} 
By involving the most ephemeral and marginal local societies traditionally excluded from decision-making processes, it is possible to create new spaces of co-evolution in the city (Cupers 2005).

Just like in the natural world, the greatest diversity is present in the intermediate areas, hybrid and liminal, of transition between different habitats, on which depend the evolutionary possibilities of the entire hosting system.

The interstitial spaces, empties within the city, have an evocative potential on perception, because the absence of use and activities that take place there, generate a sense of freedom and expectation (Berger 2007): these are the reasons behind the experience gained by a group of architects and artists in Belo Horizonte.

$10 \%$ of the city's private areas are in fact empty lots which are sometimes used illegally as parking lots or fields to grow wheat, cassava, vegetables or other crops. So, the working group thought they could transform the empty lots, although private, in temporary public spaces, after negotiating the use and the loan with the owners.

"By the use of empty lots other dynamics are established, other behaviours appear, and new local programs can be developed. They can be transformed into gardens, meeting spaces, experimentation of the nature in the micro urban scale.

There we can raise milk cattle, stretch wet clothes, put plastic pools, make wedding, familiar parties and picnics, they can be used as living-rooms, places for collective $\mathrm{TV}$-watching and to listen crickets.

The gardens can be of vegetables, flower beds, or little savage gardens. They can constitute spaces for products exchange, places for rest or reading, for star observation, or activities as games, hairdressers' shop, small musical concerts, etc. ... Those possible programs are far from speculation, since the local population can construct them, be ephemeral and be constitutive of new ecologies and systems. I believe it is a way of resistance to the society of control" (Cardoso Ganz 2008).

A similar project was proposed in Seville in 2004 by Santiago Cirugeda, whose subversive design practice provides projects tools and "recipes"-purposely publicised through his website ${ }^{12}$-for citizens who can adopt them to solve their problems in the use of space, exploiting the gaps and ambiguities of the building and urban regulations in force in particular places of the city such as those of results, empty or abandoned.

In some way it is a work that borders on legality, directed above all to the creation of public and residential spaces, of struggle and empowerment, without that they can be properly defined as illegal.

${ }^{12}$ The website is http://www.recetasurbanas.net. Accessed 12 Aug 2020.
An evocative example is the "House insect" project, which reacts to the intentions of Seville municipality to cut all the few trees still standing in the Alameda neighbourhood. Cirugeda's "recipe" envisions light structures to be placed on the trees at a height of four and a half meters, to hosting the citizens opposing to the municipality action.

"His approach is a good example of how spatial agency is embedded in a temporal continuity, in which the architect acts as catalyst of change for an unspecified period of time. Cirugeda's proposals consist of perpetually redefining global systems (urban planning and legislation), looking for possible loopholes and uncertainties that might empower the various user groups" (Schneider and Till 2009).

Ponte Guapo Isidoro $^{13}$ is an experience (started in 2013) of Recetas Urbanas in the centre of Seville, born out of the desire of San Isidoro public school students' parents for a more liveable school courtyard, an apparently unrealistic intention because of the lack of public funding.

Their proposal envisions several actions: planting two trees, building another wooden one, installing a pergola with recovered flower beds and climbing plants and finally installing an awning. The children were also involved through the support of the collective La Jarapa, which organized workshops of murals allowing to improve the patio quickly and on budget.

One of the latest experiences of Recetas Urbanas was the Art Basel event in 2018, a project to reflect about the city as a place to live and where to establish cooperative relationships between citizens, and to discuss their role and responsibilities as potential carriers of changes in the urban environment, both individually and collectively.

The outcome is a structure designed and built collectively during a series of workshops open to people of all ages, abilities and skills. At the end of the event the structure was dismantled and rebuilt in Madrid to be reused by a local association (Guzmán 2018).

Campement Urbain also operates on the construction of public space in difficult and marginal contexts. It is a group of artists, architects and urban planners established in 1999 that mixes non-hierarchized knowledge and practice involving local societies to experiment new urban spaces.

One of their most interesting projects is Je E Nous (2003-2008) carried out in Sevran Beaudottes, in the north banlieu of Paris.

\footnotetext{
${ }^{13}$ See http://www.recetasurbanas.net/v3/images/fichas/ficharefi006pontegua poisidoro.pdf. Accessed 12 Aug 2020.
} 
The intent of Campement Urbain is to create a space of "great urban tension, a singular place available to all", for which everyone feels responsible.

"A useless place, extremely fragile and not productive" to stop in alone to experience solitude, although within a collective space. A new public space that allows everyone to leave their community, not by denial or escape, but by the desire to be alone at some point" (Cosson et al. 2005)... in the sense that it is by claiming the desire to be alone that one can afford to think about being with others.

The conflictual compresence in the district of Maghrebi, Africans, Indians, and Asian citizens of the former Eastern European countries led the collective to wonder about the possibility of building a protected space in a context accustomed to daily violence, a place visited by everybody on their own, but not subjected to the religious rules.

The residents encouragingly answered, "what you propose is an extreme luxury" and "who holds the keys?" (Cosson et al. 2005).

The urban intervention at Liverpool Granby Four Streets was directed by the collective Assemble. It started in 2013 and in 2015 it was awarded with the prestigious Turner Prize. The work shows once again how in the marginal areas, in this case a multi-ethnic neighbourhood plagued by unemployment, depopulation, and degradation, a spontaneous process of empowerment can arise.

The collective grafts on these processes by means of small bottom-up interventions, as a form of opposition against extended and unitary top-down plans, often prone to failure, with an approach recalling previous experiences such as equity planning (Krumholtz and Clavel 1986, 1994; Krumholtz and Forester 1990; Krumholz 1994; Metzger 1996).

"In 2011, Granby residents entered into an innovative form of community land ownership, the Granby Four Streets CLT with the intention of bringing empty homes back into use as affordable housing. Assemble worked with the Granby Four Streets CLT and Steinbeck Studios to present a sustainable and incremental vision for the area that builds on the hard work already done by local residents and translates it to the refurbishment of housing, public space and the provision of new work and enterprise opportunities. The approach was characterized by celebrating the value of the area's architectural and cultural heritage, supporting public involvement and partnership working, offering local training and employment opportunities and nurturing the resourcefulness and DIY spirit that defines the four streets." ${ }^{14}$

\footnotetext{
${ }^{14}$ See https://assemblestudio.co.uk/projects/granby-four-streets-2. Accessed 12 Aug 2020.
}

\section{The designer and user role}

Transition spaces are territories where contradictions, ambiguities, mutations and transformations are almost constitutive. They live in a constant tension towards the future, taking the chance of designing it in a hybrid way (Anzaldua 1987), as the previous examples show, mixing different approaches and forms of rationalities. Hybrid design experiences in transition spaces can be laboratories for institutional change in which creativity plays a relevant role in order to create something that is radically new (spaces, uses, institutions, organizations, languages) (Alvarex 1995; Blatter 2003; Church and Reid 1999; Karvonen and van Heur 2014; Kurath 2018; Oldenhof et al. 2020; Perkmann 2003; Smouts 1998).

Their character makes them propitious to radical, alternative and spontaneous practices, which bring flexibility into play-for example the works of Orizzontale or the design for the square for the historical centre of Sassariwhere sometimes the user can occupy, modify or even destroy the new space and its architecture (Hill 1998a, 1998b).

Being unplanned spaces, not subject to the rules and constraints of traditional design, or being forgotten, marginal, or even cross-border, they appear as laboratories of institutional change.

Sometimes the ambiguity that characterizes them also from the legislative point of view means that they can become temporary public spaces as in the examples of Belo Horizonte or Seville. In these examples, creativity plays a fundamental role.

Moreover, the transition spaces can be places where people can renegotiate their identity through forms of empowerment, as in the project Je E Nous, where the traditional rules of space construction are completely subverted, or in the project "House insect" by Cirugeda, in the rediscovered equity planning of Assemble.

Although the projects illustrated are not on the same scale, nor necessarily imply a direct action on the space by the user, as moving, modifying, building or transforming architectures, they all have in common the user presence and the relationship, sometimes synesthetic, established by means of design actions, which determines meaning and value.

The design experiences in transition spaces identify users as the creative and productive element ${ }^{15}$ because they are co-authors and co-producers in the design of spaces and places (Hill 2003) and introduce concepts such as adaptation, reinterpretation and appropriation

\footnotetext{
15 The contemporary designer's role, rather than creating a fixed setting for people's lives, can now be perceived as a sort of facilitator for the building user to create their own place that they can change as frequently as they wish (Kronenburg 2007).
} 
that arise from the way people use, reuse, abuse or abnormally use ${ }^{16}$ urban spaces and what they contain.

The opportunity represented by transition and blurred spaces suggests the development of "intelligent", pioneering design in which urban space is not merely contemplated or crossed, but occupied, touched, ${ }^{17}$ tasted or listened to (Luz 2006).

They are spaces that suggest reversible and not resolutive design, that are therefore more like processes than as interventions defined once and for all.

These case studies highlight a change in the designer's role, who no longer just takes care of architectural objects and their construction, as in traditional practices, but, acting in an "illegal, politicized" way, favours the user experience becoming a craftsman with a sensitive and relational background instead of a modeler of architectural objects (Guattari 1996a).

As Bell and Wakeford (2008) state, the outcome of architecture is not only a set of objects and spatial devices, but above all the life quality of local inhabitants and societies.

In current "iconic" architecture, in the design of "corporate" space, especially in the media of the star system, spectacular or contemplative, there is no relationship with the user.

The value and the sense are self-referential, as if the designer worked for his exclusive satisfaction and not for another subject, whether individual or collective.

But exactly a collective subject is the only one that can give the space a meaning, and therefore enable the regeneration of public space and favour processes of appropriation of space and, consequently, the possibility of colonization and urban self-organization.

A practitioner emerges, who refuses to be "as a cog in the wheel of capitalist urbanization, as much constructed by as constructor of that process" (Harvey 2000b, p 237).

Designers still play a fundamental role, but staying in the background, almost unrecognizable: they sacrifice notoriety to an ethic that recognizes users as protagonists, thus rejecting the logic of branding, no matter if related to economic, institutional, political or personal subjects.

Urban practices in transition spaces require practitioners to put themselves at the service of inhabitants, postulate an "immersion" in context, and need the elimination of the epistemological barriers-excluding by nature-that characterize traditional patterns, to include

\footnotetext{
${ }^{16}$ Crosta (2010) which highlights how (spontaneous) practices derive from fruition and not from intentional planning and Friedman (2009) which illustrates the importance of the role of habitants in placemaking.

17 It is not by chance that Bianchetti (2016) speaks of public space defined by bodies.
}

contextualized forms of rationality that favour collective learning and empowerment of local societies.

The immersion in transition situations-"marginal" and "weak" - not only draws the attention of the planner or designer on the need of resolving specific problems, but also to stimulate the empowerment and the activation of a commitment based on a principle of inescapable responsibility.

The designer follows and stimulates the practices (Anderson 2014; Gámez and Rogers 2008) by contributing with his specific knowledge and his ethical intent, providing an action of support to the community in the recognition of their weaknesses and their potential, especially with regard to visions and projects that are externally elaborated.

Moreover, any form of intervention, other-directed, or directly derived from the technical sphere, closed to diversity and to non-technical forms of rationality, can distort the main quality of transition areas, which is their being the space of becoming, of co-evolution within diversity, between external and internal, between city and country, between natural and artificial, between public and private, between used and abandoned, between order and chaos, between institutions and anarchists, and among different societies and cultures, etc.

By allowing for some margins of freedom and therefore establishing a gradient of activation, users have a chance to modify and transform continuously their own life space and to self-organise actions by means of spontaneous practices, in the course of which "pioneering urban species" can emerge, capable of preparing the urban space to accommodate more evolved situations, new embryos of urbanity.

But, to a closer look, these new urban embryos require a different kind of users: as shown by the illustrated cases, they need mainly citizens.

Working on users' empowerment in order to transform them into citizen builds the core of a true alternative practice, affecting the political sphere, the collective identity, the assumption of responsibility.

It is something that also has to do with the capacity of our spaces of life to live and survive against exogenous forces. But this capacity ensues from users, from a social groups, that activate citizens' leadership to transform the city in a political, collective, responsible, cohesive way.

\section{Acknowledgements \\ Not applicable.}

Authors' contributions

The author read and approved the final manuscript.

Funding

The paper is funded by Sassari University: "University fund for research 2019". 


\section{Availability of data and materials}

Not applicable.

\section{Ethics approval and consent to participate}

Not applicable.

\section{Consent for publication}

Not applicable.

\section{Competing interests}

We declare that we have no competing interests.

Received: 25 August 2020 Accepted: 3 November 2020

Published online: 12 November 2020

\section{References}

Alvarex RR (1995) The Mexican-US border: the making of an anthropology of borderlands. Ann Rev Anthropol 24:447-470. https://doi.org/10.1146/ annurev.an.24.100195.002311

Amphoux P (2003) Progetto urbano. Approccio interdisciplinare e ibridazione della conoscenza. In Maciocco G, Pittaluga P (a cura di) Territorio e progetto. FrancoAngeli, Milano, pp 126-136

Anderson NM (2014) Public interest design as praxis. J Architect Educ 68(1):1627. https://doi.org/10.1080/10464883.2014.864896

Anzaldua GE (1987) Borderlands/La Frontera. Spinsters/Aunt Lute, San Francisco

Bailey N (2010) Understanding community empowerment in urban regeneration and planning in England: putting policy and practice in context. Plan Pract Res 25(3):317-332. https://doi.org/10.1080/02697 459.2010.503425

Beard V (2003) Learning radical planning: the power of collective action. Plan Theory 2(1):13-35. https://doi.org/10.1177/1473095203002001004

Bell B, Wakeford K (eds) (2008) Expanding Architecture: design as activism. Metropolis Books, New York

Berger A (2007) Drosscape: wasting land urban America. Princeton Architectural Press, New York

Bey H (1991) Temporary autonomous zone. Autonomedia, New York Bhabha H (1990) The third space: interview with Homi Bhabha. In: Rutherford $J$ (ed) Identity: community, culture, difference. Lawrence \& Wishart, London, pp 207-221

Bhabha H (1994) The location of culture. Routledge, New York

Bhabha H (1996) Aura and agora: on negotiating rapture and speaking between. In: Francis R (ed) Negotiating rapture: the power of art to transform lives. Museum of contemporary art, Chicago, pp 8-17

Bhabha H (2001) I luoghi della cultura. Meltemi, Roma

Bianchetti C (2016) Spazi che contano: il progetto urbanistico in epoca neoliberale. Donzelli, Roma

Blatter J (2003) Beyond hierarchies and networks: institutional logics and change in transboundary spaces. Governance 16(4):533-536. https:// doi.org/10.1111/1468-0491.00226

Boddington A (1999) Editorial. In: Boddington B, Cruz T (eds) Architecture of the borderlands. Wiley, Chichester, pp 4-5

Brighenti AM (ed) (2013) Urban interstices: The aesthetics and the politics of the in-between. Ashgate, Burlington

Brunet-Jailly E (2011) Borders, borderlands and theory. An introduction. Geopolitics 16(1):1-6. https://doi.org/10.1080/14650045.2010.493765

Campos DA, García CP (2004) Integración social en espacios de borde: apuntes para un caso de estudio en Lo Barnechea, Santiago. Revista de Geografía Norte Grande 32:55-69

Cardoso Ganz LM (2008) Empty lots: collective action of experimental urban occupation. In: Ruby l, Ruby A (eds) Urban transformation. Ruby Press, Berlin, pp 164-169

Cassano F (1997) Sapere di confine. La frontiera come luogo epistemologicamente più alto, Pluriverso 1:22-30

Cellamare C (2019) Città fai-da-te. Tra antagonismo e cittadinanza, Storie di autorganizzazione urbana, Donzelli, Roma

Church A, Reid P (1999) Cross-border co-operation, institutionalization and political space across the English Channel. Region Stud 33(7):643-655. https://doi.org/10.1080/00343409950078684
Cicalò E (2001) Frammenti di urbanità. II progetto ambientale in un'area di bordo. In Maciocco G, Pittaluga P (a cura di), La città latente, FrancoAngeli, Milano, pp 58-77

Cicalò E (2006) Margini di libertà. Conflitti e contraddizioni dello spazio pubblico. In Maciocco G, Pittaluga P (a cura di), II progetto ambientale in aree di bordo. FrancoAngeli, Milano, pp 78-89

Clément G (2004) Manifeste du tiers paysage. Sujet/Objet, Paris

Cohen P (2000) From the other side of the tracks: dual cities, third space, and the urban uncanny in contemporary discourses of "race" and class. In: Bridge G, Watson SA (eds) A companion to the city. Blackwell, Oxford, pp 316-330

Corner J (2001) Landscraping. In: Daskalakis G, Waldheim C, Young J (eds) Stalking Detroit. Actar, Barcelona, pp 122-125

Cosson M, Le Brun-Cordier P, Osganian P (2005) Campement urbain: je et nous, un lieu de solitude désirée. Mouvements 39-40:103-111. https:// doi.org/10.3917/mouv.039.0103

Crosta PL (2010) Pratiche: il "territorio è l'uso che se ne fa". FrancoAngeli, Milano

Cupers K (2005) Towards a nomadic geography: rethinking space and identity for the potentials of progressive politics in the contemporary city. Int J Urban Reg Res 29(4):729-739. https://doi.org/10.111 1/j.1468-2427.2005.00619.x

De Certeau M (1984) The practice of everyday life. California University Press, Berkeley, CA

de Sola Morales RI (1995) Terrain Vague. In: Davidson C (ed) Anyplace. The MIT Press, Cambridge, pp 118-123

Douglas GC (2018) The help-yourself city: legitimacy and inequality in DIY urbanism. Oxford University Press, Oxford

Douglas M, Friedmann J (eds) (1998) Cities for citizens: planning and the rise of civil society in a global age. Wiley, New York

Entrikin N (1991) The betweenness of place. Johns Hopkins University Press, Baltimore

Finn D (2014) DIY urbanism: implications for cities. J Urban 7(4):381-398. https ://doi.org/10.1080/17549175.2014.891149

Foucault M (1994) Eterotopia. Millepiani 2:7-20

Foucault M (1998) Different spaces. In: Faubion JD (ed) Aesthetics, method, and epistemology: essential works of Foucault 1954-1984, vol two. The Penguin Press, London, pp 175-185

Friedman J (1992) Empowerment: the politics of alternative development. Blackwell, Cambridge

Friedman J (2000) Claiming rights: citizenship and the spaces of democracy. Plurimondi 2:287-303

Friedman J (2009) Place and place-making in cities: a global perspective. http://www.scarp.ubc.ca/users/john-friedmann. Accessed 10 Sept 2020

Fung A (2004) Empowered participation: reinventing urban democracy. Princeton University Press, Oxford

Furuseth OJ, Lapping MB (eds) (1999) Contested countryside: the rural urban fringe in North America. Ashgate, Aldershot

Galdini R (2017) Ripensare gli spazi pubblici. Usi temporanei e pratiche informali a Berlino. Sociologia urbana e rurale 113:103-119. https://doi. org/10.3280/SUR2017-113007

Gallant N, Andersson J (2007) Representing England's rural-urban fringe. Landsc Res 32(1):1-21. https://doi.org/10.1080/01426390601097495

Gallant N, Andersson J, Bianconi M (2004) Vision for a sustainable multifunctional rural-urban fringe. Countryside Agency, Cheltenham

Gallant N, Andersson J, Bianconi M (2006) Planning on the edge. The context for planning at the rural-urban fringe. Routledge, London \& New York

Gámez JLS, Rogers S (2008) An Architecture of Change. In: Bell B, Wakeford $\mathrm{K}$ (eds) Expanding architecture: design as activism. Metropolis Books, New York

Greif G, Cruz M (1999) Reconstructing urban boundaries: the dialectics of self and place. Cybergeo. https://doi.org/10.4000/cybergeo.1185

Guattari F (1991) Le tre ecologie. Sonda, Torino-Milano

Guattari F (1996a) Caosmosi. Cta \& Nolan, Genova

Guattari F (1996b) Cartografia schizoanalitica. Millepiani 7:25-32

Gutiérrez K, Baquedano-Lopez P, Alvarez T (1999) A cultural-historical approach to collaboration: building a culture of collaboration through hybrid language practices. Theory Pract 38(2):87-93. https://doi. org/10.1080/00405849909543837

Gutiérrez K, Baquedano-Lopez P, Tejeda C (2000) Rethinking diversity: hybridity and hybrid language practices in the third space. Mind Cult Act Int J 6(4):286-303. https://doi.org/10.1080/10749039909524733 
Guzmán K (ed) (2018) Usted está aquí. Recetas Urbanas, Musa, León Hajer M, Reijndorp A (2001) In search of new public domain. NAi Publishers, Rotterdam

Hall S (1996) Ethnicity: identity and difference. In: Eley G, Suny RG (eds) Becoming national. A reader. Oxford University Press, Oxford, pp 339-351

Harvey D (2000a) Frontiers of insurgent planning. Plurimondi 2:269-286 Harvey D (2000b) Spaces of hope. Edinburgh University Press, Edinburgh

Hazel A, Les R (eds) (2012) Liminal landscapes travel, experience and spaces in-between. Routledge, London

Hill J (1998a) The illegal architect. Black Dog Publishing Limited, London

Hill J (ed) (1998b) Occupying architecture: between the architect and the user. Routledge, London

Hill J (2003) Actions of architecture: architects and creative users. Routledge, London

Holston J (1998) Spaces of insurgent citizenship. In: Sandercock L (ed) Making the invisibile visisble: a multicultural planning history. California University Press, Berkeley, pp 37-56

Holston J (2008) Insurgent citizenship: disjunctions of democracy and modernity in Brazil. Princeton University Press, Princeton

Horvath A, Thomassen B, Wydra H (eds) (2015) Breaking boundaries: varieties of liminality. Berghan, Oxford

Hou J (ed) (2010) Insurgent public space: guerrilla urbanism and the remaking of contemporary cities. Routledge, London

lossifova D (2013) Searching for common ground: urban borderlands in a world of borders and boundaries. Cities 34:1-5. https://doi. org/10.1016/j.cities.2013.01.006

Jones R (2009) Categories, borders and boundaries. Progr Hum Geogr 33:174-189. https://doi.org/10.1177/0309132508089828

Karvonen A, van Heur B (2014) Urban laboratories: experiments in reworking cities. Int J Urban Reg Res 38(2):379-392. https://doi. org/10.1111/1468-2427.12075

Kronenburg R (2007) Flexible, architecture that responds to change. Laurence King, London

Krumholtz N, Clavel P (1986) The progressive city: planning and participation. Rutgers University Press, New Brunswick

Krumholtz N, Clavel P (1994) Reinventing Cities. Temple University Press, Philadelphia

Krumholtz N, Forester J (1990) Making equity planning Work. Leadership in the public sector. Temple University Press, Philadelphia

Krumholz N (1994) Dilemmas in equity planning: a personal memoir. Plan Theory 10(11):45-56

Kurath M (2018) Constructing the urban citizen: how public knowledge is translated into urban planning processes. In: Kurath M, Marskamp M, Paulos J, Ruegg J (eds) Relational planning. Palgrave Macmillan, London, pp 121-149

Lane M (2000) Indigenous people and resource planning in Northern Australia, reshaping or reproducing existing practice. Plurimondi 2:181-192

Leontidou L (1996) Alternatives to modernism in (southern) urban theory: exploring in-between spaces. Int J Urban Reg Res 20(2):180-197. https ://doi.org/10.1111/j.1468-2427.1996.tb00310.x

Lévesque L (2002) Interstitial landscapes as resources. Few thoughts about a tactical approach to urban intervention. XXI World Congress of Architecture (UIA), Berlin. http://www.amarrages.com/amarrages/ amar_textes/amar_textes_eng.html. Accessed 25 Aug 2020

Lévesque L (2003) Intervention mobilière et vie urbaine: notes intercalaires sur un processus d'amarrages. Inter: art actuel 85:56-59

Lim W (2001) Space of indeterminacy. In: Proceedings of conference bridge the gap, Fukoka, 24-27 July 2001

Luz A (2006) Places in-between: the transit(ional) locations of nomadic narratives. In: Näripéa E, Sarapik V, Tomberg J (eds) Place and location. Studies in environmental aesthetics and semiotics, Paik, Tallin, pp 143-165

Marras A (ed) (1999) ECO-TEC: architecture of the in-between. Princeton Architectural Press, New York

Merrifield A (2000) Henri Lefebvre: a socialist in space. In: Crang M, Thrift N (eds) Thinking space. Routledge, London, pp 67-182

Metzger JT (1996) The theory and practice of equity planning: an annotated bibliography. J Plan Literature 1(1):112-126. https://doi. org/10.1177/088541229601100106

Miraftab F (2009) Insurgent planning: situating radical planning in the global south. Plan Theory 8(1):32-50. https://doi.org/10.1177/1473095208 099297
Mukhija V, Loukaitou-Sideris A (eds) (2014) The informal American city: beyond taco trucks and day labor. MIT Press, Boston

Oldenhof L, Rahmawan-Huizenga S, van de Bovenkamp H, Bal R (2020) The governance challenge of urban living laboratories: using liminal "inbetween" space to create livable cities. In: van Montfort C, Michels A (eds) Partnerships for Livable Cities. Palgrave Macmillan, London, pp 293-315

Paba G (2003) Movimenti urbani: pratiche di costruzione sociale della città. FrancoAngeli, Milano

Perkmann M (2003) Cross-border regions in Europe. Eur Urban Regional Stud 10(2):153-171. https://doi.org/10.1177/0969776403010002004

Pile S (1997) Introduction_opposition, political identities and space of resistance. In: Keith M, Pile S (eds) Geographies of resistance. Routledge, London/New York, pp 1-32

Routledge P (1996) The third space as critical engagement. Antipode 28:399419. https://doi.org/10.1111/j.1467-8330.1996.tb00533.x

Roy A (2005) Urban informality: toward an epistemology of planning. J Am Plan Assoc 71(2):147-158. https://doi.org/10.1080/01944360508976689

Roy A (2009) Strangely familiar: planning and the worlds of insurgence and informality. Plan Theory 8(1):7-11. https://doi.org/10.1177/1473095208 099294

Sabatini F, Arenas F (2000) Entre el Estado y el Mercado: resonancias geográficas y sustentabilidad social en Santiago de Chile. Eure 26(79):95-113. https://doi.org/10.4067/S0250-71612000007900006

Sandercock L (2000) Translations: from insurgent planning practices to radical planning discours. Plurimondi 2:37-46

Schneider T, Till J (2009) Beyond discourse: notes on spatial agency. Footprint 1:97-112. https://doi.org/10.7480/footprint.3.1.702

Sievert T (2003) Cities without cities: an interpretation of the Zwischenstadt. Spon Press, London

Singh N, Titi V (eds) (1995) Empowerment for sustainable development: toward operational strategies. Zed Books, Nova Scotia

Smith C (2001) Looking for liminality in architectural space. Limen 1. http:// limen.mi2.hr/limen1-2001/index.html. Accessed 25 Aug 2020

Smouts M-C (1998) The region as the new imagined community. In: Le Galès P, Lequesne C (eds) Regions in Europe. Routledge, London, pp 30-38

Soja EW (1989) Postmodern geographies: the reassertion of space in critical social theory. Verso, New York

Soja EW (1996) Thirdspace: journeys to Los Angeles and other real-imagined places. Blackwell, Oxford

Soja EW (2000) Thirdspace: expanding the scope of the geographical imagination. In: Read A (ed) Architecturally speaking. Routledge, London, pp $13-30$

Stefani B (2019) II collettivo HPO si presenta: architettura e design hanno una nuova casa. https://www.filomagazine.it/2019/10/il-collettivo-hpo-sipresenta-architettura-e-design-hanno-una-nuova-casa/. Accessed 12 Aug 2020

Swerts T (2017) Creating space for citizenship: the liminal politics of undocumented activism. Int J Urban Reg Res 41(3):379-395. https://doi. org/10.1111/1468-2427.12480

Tagliagambe S (1997) Epistemologia del confine. II Saggiatore, Milano

Talen E (2015) Do-it-yourself urbanism: a history. J Plan History 14(2):135-148. https://doi.org/10.1177/1538513214549325

Thomassen B (2014) Liminality and the modern: living through the inbetween. Ashgate, Farnham

Van Ballegooijen J, Rocco R (2013) The ideologies of informality: informal urbanisation in the architectural and planning discourses. Third World Quart 34(10):794-1810. https://doi.org/10.1080/01436597.2013.851890

van Houtum H, Kramsch O, Zierhofer W (2005) B/ordering space. Ashgate, Adelshot

Waldheim C, Santos-Munne M (2001) Decaming detroit. In: Daskalakis G, Waldheim C, Young J (eds) Stalking detroit. Actar, Barcelona, pp 104-121

Weissberg R (1999) The politics of empowerment. Praeger, Westport

Worpole K, Knox K (2007) The social value of public spaces. Joseph Rowntree Foundation, York

\section{Publisher's Note}

Springer Nature remains neutral with regard to jurisdictional claims in published maps and institutional affiliations. 